\title{
Kønsmæssige minoriteter
}

\section{- når mænd bliver sygeplejersker og kvinder politibetjente}

Af Stine Thidemann Faber

Trods mange airs ligestillingsarbejde er det stadig sardeles vanskeligt at bryde med de traditionelle kønsmønstre på arbejdsmarkedet. Det er bestemt ikke er uproblematisk bverken at vare mand $i$ et kvindefag eller kvinde $i$ et mandefag. Hvilke erfaringer har mandlige sygeplejersker og kvindelige politibetjente med kon og ligestilling $i$ deves arbejde?

\section{E S S A Y}

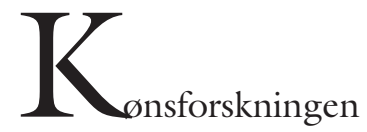
har længe fokuseret på at dokumentere barriererne for kvinder på arbejdsmarkedet; herunder vilkårene for kvinder, som trænger ind i traditionelle mandefag. En stor del af denne forskning kan føres tilbage til Rosabeth Moss Kanters efterhånden klassiske 'token'-teori (Kanter 1977a). Ifølge Kanter bliver individer "tokens", når de udgør en så lille minoritet, at de bliver betragtet som symboler på deres sociale kategori nærmere end som individer. Kanter knytter tre forskellige tendenser til 'token'-situationen:

For det første gælder, at individer, der er i mindretal i organisationer, skiller sig ud og derfor er sterkt synlige, hvilket skaber et øget pres med hensyn til de faglige præstationer. For det andet gxlder, at majoriteten tendentielt skaber kontrast til eller overdriver forskellighederne mellem dem selv og de få. Dette fordi tilstedeværelsen af et 'token' medfører, at majoritetens opmærksomhed omkring, hvad de selv har til fælles, skærpes, i takt med at disse fællestræk trues 
- i det øjeblik gruppen står overfor en "outsider", begynder gruppemedlemmerne for alvor at se sig selv som "insiders". Da 'tokens' er for få til at alliere sig og generere en modkultur, har de ikke mange andre valgmuligheder end at acceptere isolation eller søge at blive en "insider" ved at vende ryggen til deres egen sociale kategori. Den tredje og sidste tendens er assimilation. 'Tokens' kan ifølge Kanter aldrig blive set for, hvem de i virkeligheden er, men må altid kæmpe mod stereotyper og tøjle deres adfærd efter andres vilje og ønsker. Dét, at 'tokens' bliver bundet af stereotype forventninger til deres art/kategori, er i majoritetens interesse, idet de derved kan falde tilbage på deres forudfattede forventninger samt traditionelle adfærd og følgelig undgå usikkerhed og forvirring. Ofte oplever 'tokens' det lettere at tilpasse sig de stereotype roller end at bekæmpe dem; dette er imidlertid forbundet med personlige konsekvenser for det enkelte 'token' (Kanter 1977a, 1977b).

\section{MERE END BLOT ET SPØRGSMÅL OM ULIGEVÆGT I ANTALSFORHOLD}

Selvom forskningen omkring det kønsopdelte arbejdsmarked overvejende har været koncentreret om at dokumentere barriererne for kvinder i mandefag, er også forskning om vilkårene for mænd i kvindefag efterfølgende kommet til. Megen af denne forskning (fx Williams 1995) har afvist, at Kanters teori skulle gxlde for minoriteter generelt; i stedet er der fra flere sider blevet argumenteret for, at de problemer og barrierer, som de Kanterske kvinder møder, er begrundet i kvindernes lavere status i det omgivende samfund snarere end i deres mindretalsposition i organisationen (for uddybning af skandinavisk kritik se fx Kvande \& Rasmussen 1990; Lindgren 1985; Nexø Jensen 1990; Dahlerup 1988).

Ifølge Christine L. Williams (1995) bydes mænd velkommen i kvindefag, idet de forventes at have noget at tilføje både soci- alt og fagligt. Mænd tager deres køns privilegier med sig ind i kvindefagene, hævder Williams, og konkluderer som følge heraf, at mænd, selv når de er i mindretal, drager fordele af deres køns universelt anerkendte forrang. Og på grund af mændenes høje status i samfundet generelt, highlighter de gerne deres forskellighed i stedet for jf. Kanter at nedtone den. Williams konkluderer endvidere, at selvom kvindekulturen er dominerende i kvindefagene, tvinges mændene alligevel ikke til at assimilere eller akkomodere med denne; de kan tværtimod udvikle deres egen kultur uden at blive marginaliseret (Williams 1995).

Når Kanter fejlagtigt antager, at det er de samme tendenser og processer, som sættes i gang omkring kvinder og mænd, når de er i mindretal på arbejdsmarkedet, skyldes det, at hun i sin kønsneutrale tilgang lægger for stor vægt på gruppers relative antal i organisationer og for lidt vægt på, hvem der tilhører minoritetsgruppen $\mathrm{Og}$ ifølge Joan Acker (1991) er det problematisk at anskue arbejdsorganisationer som kønsneutrale, fordi samfundets kulturelle overbevisninger om maskulinitet og femininitet er indbygget også i organisationers strukturer. Med Ackers kønsordningsperspektiv bliver det tydeligt, at de barrierer, konflikter, magtfordelinger og interesser, som kvinder konfronteres med i mandsdominerede organisationer ikke, som Kanter hævder det, kun udspringer af numeriske fordelinger, men at det samtidig handler om, hvad det betyder at være mand og kvinde, og hvordan mænd og kvinder ordnes i forhold til hinanden. Ifølge Acker indeholder organisatoriske hierarkier, jobbeskrivelser og uformelle praksisser på arbejdspladserne alle dybt forankrede antagelser om køn og kønnede karakteristika om arbejderne: Først og fremmest er organisationerne 'kønnede' på den måde, at arbejdsgivere foretrækker arbejdskraft med få ikke-arbejds-distraktioner. Dette er ikke en kønsneutral præference, da mænd passer bedre til denne beskrivelse end kvinder pga. ulige fordelte hushold- 
ningsforpligtelser og ikke mindst kvinders fravær ved barsel (Acker 1991).

Også i kvindedominerede fag foretrækkes betingelsesløst engagement i arbejdet og derfor gxlder det selv i disse fag, at der er en præference for at ansætte mænd. Hvor Kanter konstaterer, at der i mandsdominerede fag eksisterer en modvilje mod at ansætte kvinder, finder Williams i tråd med Acker, at det modsatte gxlder i forhold til mænd i kvindefag. Ifølge Williams hviler der et decideret organisatorisk pres på mænd i kvindefag forstået på den måde, at det mere eller mindre forventes, at de gør karriere. Hvor man i kvindeforskningen opererer med begrebet 'glasloft', som betegnende for dét fænomen, at kvinder i mandefag ofte har svært ved at gøre karriere, betegner Williams følgelig dette modsatte fænomen - at mænd presses til eller forventes at gøre karriere inden for kvindefagene - som "glasrulletrappe-effekten". Glasrulletrappe-effekten er først og fremmest begrundet i, at der ofte er en overrepræsentation af mænd også i kvindefagenes administration og ledelse, hvilket resulterer i fordele for mændene ved forfremmelsesrunder; 'male bonding' i form af fælles, maskuline interesser fx for sport øger således mændenes karrierechancer. Men Williams' studie viser også, at de kvindelige kollegaer på baggrund af høje forventninger til mænd og deres kvalifikationer bidrager til glasrulletrappe-effekten, idet kvinderne selv i den daglige praksis gør forskel på kønnene, bl.a. ved at uddele specielt 'mandlige' opgaver og derved tildele mænd større autoritet og kontrol på arbejdspladsen (Williams 1995).

\section{EN INTERVIEWUNDERSØGELSE}

BLANDT MÆND I SYGEPLEJEN OG

\section{KVINDER I POLITIET}

Mænd udgør kun knap $4 \%$ af det samlede antal sygeplejersker i Danmark og kvinder blot $8 \%$ af den samlede danske politistyrke. De få mænd, der vælger sygeplejen, og de

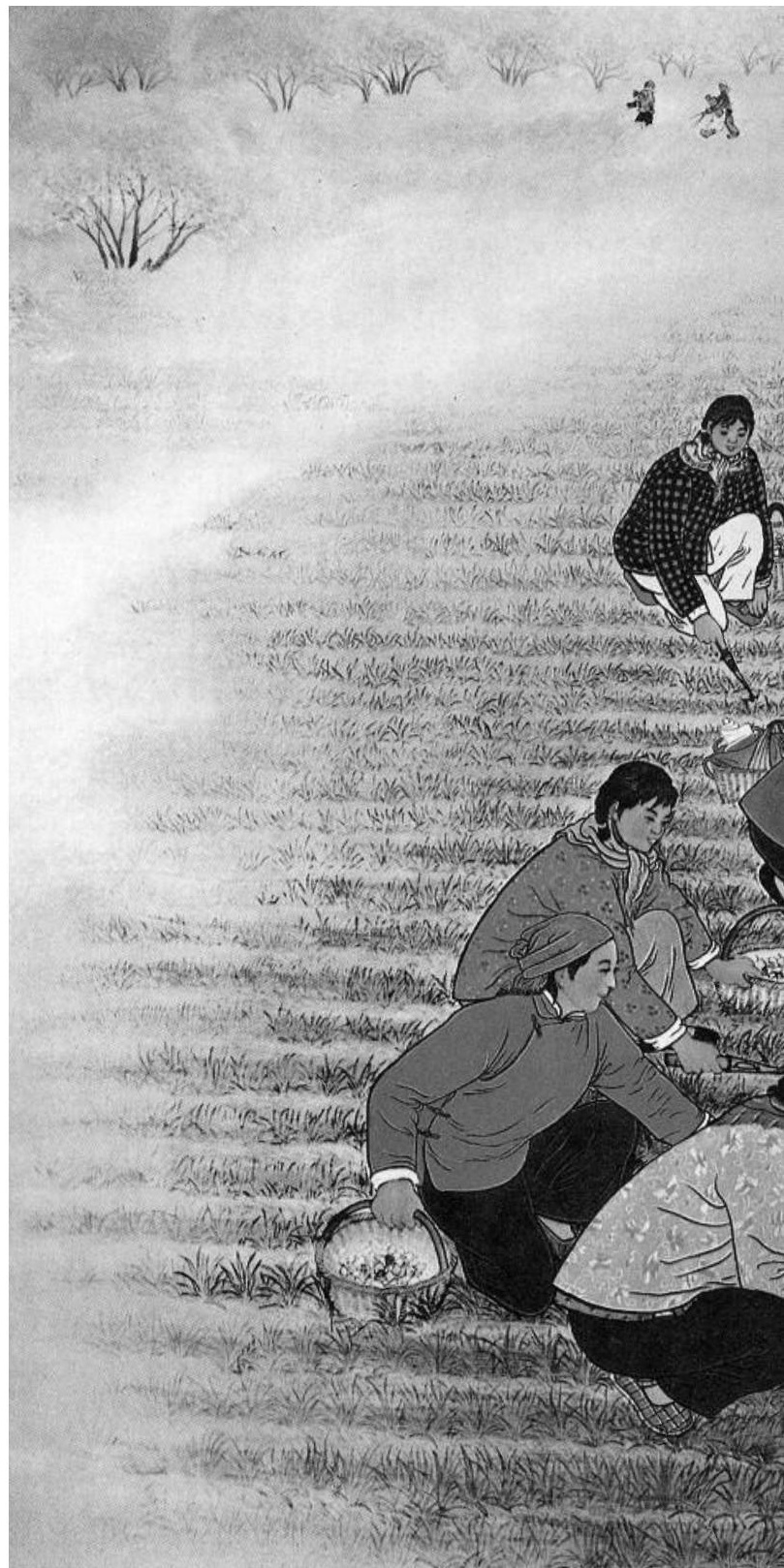




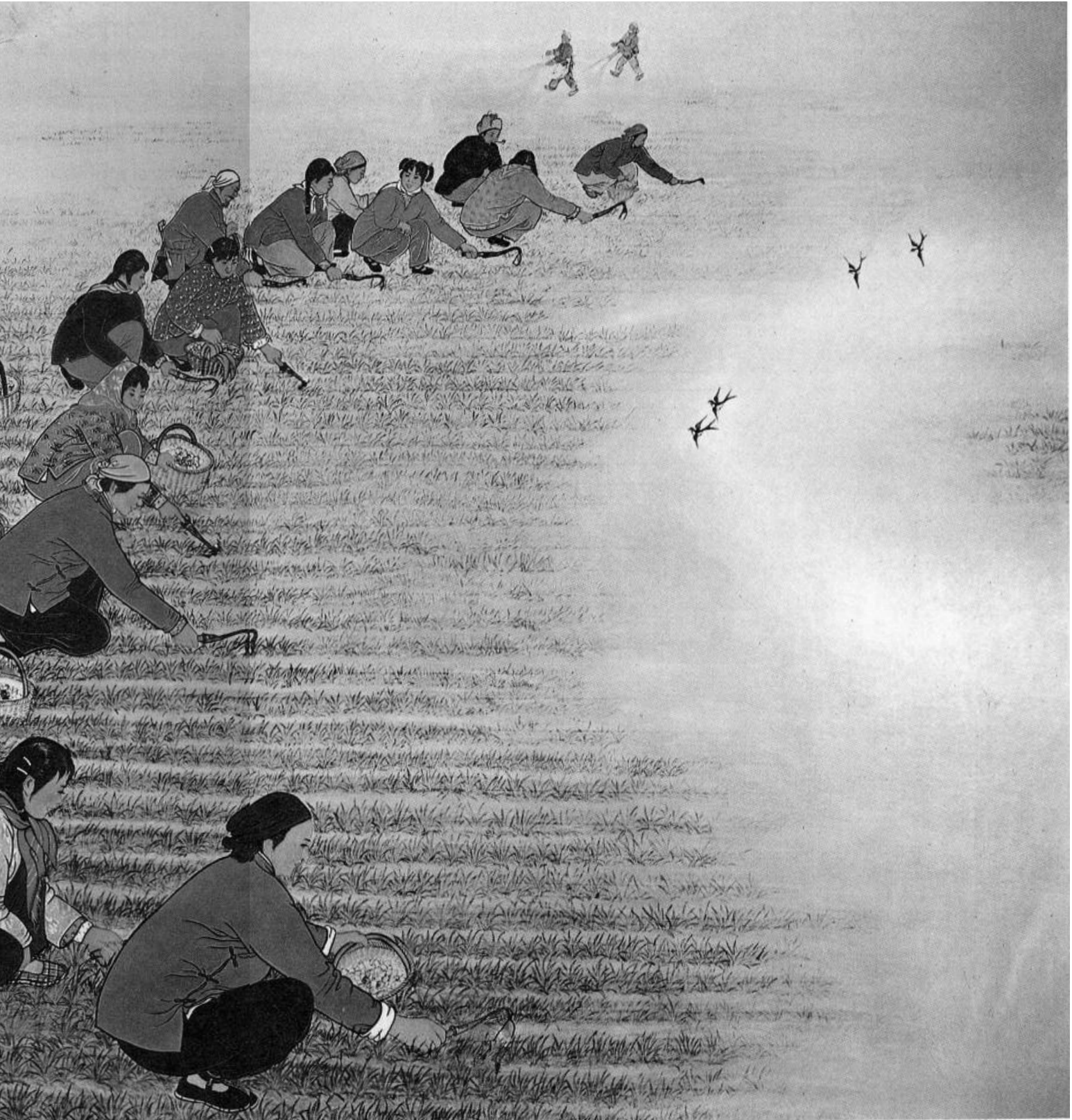

"Forårsarbejde i marken", Finn Suenson Forlag, 1978 
få kvinder, der søger ind i politiet, bliver derfor i høj grad kønsmæssige minoriteter ('tokens') inden for deres fag. Udover at være mere eller mindre enkønnede fag, kan sygeplejen og politiet også siges at være særligt kønsmærkede. Billedet af den traditionelle sygeplejerske er mere eller mindre synonymt med kvindelighed: Omsorg, pleje og moderlighed, og billedet af den traditionelle politibetjent er omvendt mere eller mindre entydigt knyttet til mandlighed: Autoritet, magt og fysisk styrke. Mandlige sygeplejersker og kvindelige politibetjente skal derfor ikke kun begå sig i fag, som antalsmæssigt domineres af det modsatte køn, men også håndtere, at $\mathrm{de} \mathrm{i}$ vid udstrækning bryder med de samfundsmæssige billeder af, hvad der er henholdsvis 'mandearbejde' og 'kvindearbejde'.

I foråret/efteråret 2002 gennemførte dette essays forfatter i samarbejde med Lotte Bloksgaard (Freia, Center for Kønsforskning, Aalborg Universitet) en interviewundersøgelse blandt en række mænd i dansk sygepleje og kvinder i dansk politi (Bloksgaard \& Faber 2004). Baggrunden for undersøgelsen, som baserer sig på interview med henholdsvis otte mandlige sygeplejersker og otte kvindelige betjente, var bl.a. et $\varnothing n s k e$ om at efterprøve Kanters teori. Selvom undersøgelsen i tråd med Kanter identificerer mange ligheder $i$ de mandlige sygeplejersker og de kvindelige betjentes arbejdsliv (mændene og kvinderne er eksempelvis enige om at føle sig ekstra synlige, uden for normen, underlagt det andet køns præmisser m.m.), er der på en række områder også væsentlige forskelle på de to køns oplevelser og håndteringer. Umiddelbart er det som Williams nærliggende at konkludere, at de mandlige sygeplejersker i langt højere grad oplever fordele af deres køn, hvor de kvindelige betjente oplever ulemper, men som det også vil fremgå af det efterfølgende, indeholder denne konklusion dog flere nuancer end Williams umiddelbart synes at levne rum for.

\section{RESULTATERNE FRA UNDERS $\varnothing$ GELSEN}

Undersøgelsen blandt de mandlige sygeplejersker og kvindelige betjente afdækker, at mændene - ganske som Williams hævder det - bydes velkommen og tendentielt betragtes som hævede over den kvindelige standard, mens de kvindelige betjente jf. Kanter i langt højere grad møder skepsis og modstand; der bliver lagt ekstra mærke til, hvad kvinderne gør, hvordan de er, og om det nu også er lige så godt, som når mændene udfylder samme funktion - det ses således, at de kvindelige betjentes kompetencer ofte betvivles, og at kvinderne (jf. også Martin 1980) først når de har bevist deres værd accepteres og regnes for pålidelige betjente:

"Som kvinde har jeg oplevet at skulle bevise, at jeg var lige så god som de andre! Jeg skulle gerne være lige lidt hurtigere til at rejse mig, når den vagthavende kom og sagde, at der skulle en vogn på gaden til en opgave. Hele tiden skulle jeg være på forkant." (Linda, betjent)

Hvad angår de kvindelige betjente kan man endvidere tale om, at de i tråd med Kanter i vid udstrækning oplever kontrast i det sociale samvær. Kvinderne synes at forstyrre de mandlige samværsformer i politiet, hvilket kommer til udtryk ved, at gruppesolidaritet og kammerateri tendentielt øges blandt mændene i faget; bl.a. finder mændene i vid udstrækning sammen i en fælles nedgørelse af kvindekønnet:

"Man skal kunne tåle at høre noget i sådan en mandeverden. Der bliver sagt grove ting. Bare jeg går ud i køkkenet, siger de eksempelvis: Bliv du derude, det kender du jo hjemmefra! Hvis man svarer igen, rotter de sig hurtigt sammen og begynder at køre på én. Så får man skudt i skoene, at man er præmenstruel eller sådan noget” (Mia, betjent)

Ingen af de mandlige sygeplejersker giver udtryk for at opleve, at deres tilstedeværelse 
i sygeplejen er decideret uønsket, og idet de mandlige sygeplejersker i vid udstrækning selv vælger at vende sig bort fra de kvindelige kollegaer og kvindesnakken, dækker begrebet 'polarisering' bedre end kontrast over dét, mændene oplever. Flertallet af de mandlige sygeplejersker differentierer sig bevidst fra kvinderne i sygeplejen ud fra en tilkendegivelse af, at de ellers "får nok":

"Indimellem kommer jeg til at lide af - hvad mandlige sygeplejersker kalder - skovmandssyndrom. Det handler simpelthen om, at man făr en vild og inderlig lyst til at havne i en lejr med ene mænd, og så bare gå og fælde træer! For nu kan det fandeme være nok!" (Kristian, sygeplejerske)

Generelt er der stor forskel på, hvordan de kvindelige betjente og de mandlige sygeplejersker tackler det faktum, at de kønsmæssigt er i mindretal på deres arbejdsplads. Kvindernes beretninger efterlader et klart indtryk af, at de jf. Kanter i vid udstrækning opfattes som repræsentanter for deres køn. De skal hele tiden passe på ikke at være anledning til konklusionen: 'Kvinder egner sig ikke til jobbet som betjent, kvinder passer ikke ind her!'. Af denne grund tilstræber de kvindelige betjente at være en del af helheden, hvilket bl.a. kommer til udtryk ved, at de undlader at søge sammen:

"Jeg tror ikke, at kvindenetværk i politiet har særlig mange pigers interesse, fordi de ikke tør skille sig ud. Det vil jo straks blive kaldt for en rødstrømpebevægelse eller et eller andet lignende, og mændene vil gå på barrikaderne" (Birgitte, betjent).

Det faktum, at de kvindelige betjente, selv om de er så få i deres fag, undlader at søge sammen, står i skarp kontrast til, hvad der er gældende blandt mændene i sygeplejen. Flere af de mandlige sygeplejersker fortæller nemlig, at de bevidst søger til specialer i sy- geplejen, som har en stor koncentration af mænd (f.eks. skadestuen og psykiatrien), og at de desuden på tværs af omsorgssektoren dyrker mandefællesskaber:

"Vi prøver at samle alle mænd inden for afdelingen dvs. både de som er sygeplejersker, teknikere, fysikere, portører og læger. Der er lidt broderskab over det." (Lennart, sygeplejerske).

Modsat de kvindelige betjente beretter ingen af de mandlige sygeplejersker om, at deres kvindelige kollegaer i sygeplejen skulle have problemer med mandefællesskaberne, hvilket peger på, at det (jf. også Hansen 1999) tilsyneladende er mere accepteret, når mænd søger mandligt samvær, end når kvinder søger kvindeligt samvær.

Mens mændene i sygeplejen trods deres minoritetsposition kan udvikle deres egen kultur uden at blive marginaliseret, er kvinderne i politiet i langt højere grad nødsaget til at acceptere den dominerende kultur. En af grundene til, at de kvindelige betjente ikke ønsker at skille sig ud, er, at de oplever, at synlig kvindelighed tendentielt forbindes med 'ikke-faglighed', og at det derfor er nemmere for dem at blive accepteret som fagligt jævnbyrdige, hvis de tilstræber at ligne mændene, såvel $\mathrm{i}$ adfærd som udseende. Mændene i sygeplejen derimod er ikke bange for at skille sig ud som mænd - de tøver ikke med fx at henlede opmærksomheden på sig selv, dels ved dannelse af maskuline modkulturer jf. ovenfor, dels ved eksempelvis at lade sig vælge som tillidsrepræsentanter, klart udtrykke deres meninger, gå i front med kritik af overordnede, etc. Forskellen på de mandlige sygeplejersker og de kvindelige betjentes beretninger, hvad angår dette punkt, skal ses i sammenhæng med, at de mandlige sygeplejersker jf. Williams oplever det faglige samarbejde helt anderledes end de kvindelige betjente. Mændene fortæller ikke blot, at de trives med den ekstra opmærksomhed, det giver at være 'ene hane i hønsegården', men og- 
så, at de nyder stor anseelse i den kvindedominerede sygepleje. De mandlige sygeplejersker føler tydeligvis ikke på samme måde som de kvindelige betjente, at de skal bevise deres værd; tværtimod tilskrives mændene lederskab, en ganske særlig autoritet og stor faglig ekspertise. Og mændene oplever, at dette syn på dem og deres køn smitter af på fordelingen af arbejdsopgaver, idet de kvindelige kollegaer ofte tilkalder dem til opgaver, som "kræver en mand" (eksempelvis tekniske opgaver, vanskelige patienter m.m.).

Hvor de mandlige sygeplejersker tillægges egenskaber som fysisk styrke, teknisk interesse, selvstændighed samt autoritet, tilskrives de kvindelige betjente i højere grad egenskaber som fysisk svaghed, indlevelse/ forståelse, uselvstændighed og tilbageholdenhed/tolerance. Det er karakteristisk, at de maskuline egenskaber og arbejdsopgaver jf. Acker tillægges større værdi end de feminine egenskaber og arbejdsopgaver, hvorfor de mandlige sygeplejersker i højere grad end de kvindelige betjente drager fordel af deres køn.

At de kvindelige betjente tillægges egenskaber efter køn, kommer bl.a. til udtryk ved, dels at kvinderne tendentielt tildeles opgaver, der involverer børn og kvindelige borgere, dels at mandlige kollegaer indimellem beder om ekstra backup og i det hele taget søger at beskytte kvinderne:

"Der har da været nogle vagthavende, som syntes, at de skulle passe på os kvinder; hvis det var sådan nogle voldsomme opgaver, tøvede de ligesom lidt med at sende os ud" (Linda, betjent).

De interviewede kvinder i politiet problematiserer ikke det faktum, at de mandlige betjente - under foregivelse af hensyntagen - rent faktisk betvivler deres kompetencer, hvilket måske handler om, at de derved står over for et paradoks: På den ene side vil de gerne have særbehandling, hvis denne er et udtryk for respekt for dem og deres femini- nitet. På den anden side vil kvinden altid være i tvivl om, hvorvidt særbehandlingen faktisk tildeles på grund af respekt, eller fordi manden ikke mener, at hun selv er kompetent til at udføre opgaven.

Hvad angår ambivalens $\mathrm{i}$ forhold til at skulle balancere mellem arbejds- og familieliv konkluderer undersøgelsen, at også her er der forholdsvis stor forskel på mændene $\mathrm{i}$ sygeplejen og kvinderne i politiet. En af grundene til, at ambivalensen er markant større hos de kvindelige betjente end hos de mandlige sygeplejersker, er, at kvinderne i politiet har sværere ved at adskille familieog arbejdsliv, idet de føler et stort personligt ansvar for børnenes/familiens trivsel. En anden og måske mere væsentlig grund er imidlertid, at der på kvindernes (mande)arbejdsplads er et meget lille rum til at prioritere familielivet. Hvor de mandlige sygeplejersker i vid udstrækning oplever dét at prioritere familielivet som en norm på deres (kvinde-)arbejdsplads, oplever de kvindelige betjente (jf. også Holt 1994), at rummet rettet mod varetagelse af familieog børnebehov er langt mere indsnævret på mandarbejdspladser:

"Hvis jeg siger, at jeg ikke gider have nattevagter, fordi jeg gerne vil se mit barn, så kigger de på mig, som om jeg er åndssvag?! Som om, de synes, at det er noget pjat. Jeg tror, at grunden til, at vi ikke får bedre vilkår, er, at her er flest mænd, og at det ikke generer dem i samme grad. Jeg er meget mere i konflikt med mig selv og hvordan jeg skal få det til at gå op, så jeg er irriteret over, at vi ikke kan finde sammen, trampe i gulvet og få nogle bedre vilkår” (Mia, betjent).

\section{AMBIVALENS KONTRA UTILPASSETHED}

Selvom man i første åndedrag er fristet til i tråd med Williams at konkludere, at 'token'-mænd har det 'lettere' end 'token'kvinder, viser interviewundersøgelsen ikke desto mindre, at mændene i sygeplejen oplever en ganske markant ambivalens. En af 
årsagerne til, at de mandlige sygeplejersker oplever ambivalens, er, at de oplever det svært at leve op til/frigøre sig fra forventningerne til deres køn; den enkelte mand, der ikke har teknisk snilde, oplever det selvsagt ubehageligt altid at blive tilkaldt til de tekniske opgaver, og med den øgede tildeling af autoritet og respekt oplever flere af mændene det generende, at andre qua deres køn tilskriver dem større ekspertise og kompetence end tilfældet er. Også hvad angår den statusnivellering, som mændene $\mathrm{i}$ sygeplejen dagligt møder, viser undersøgelsen, at de mandlige sygeplejersker oplever rådvildhed - når mændene $\mathrm{fx}$ møder positiv statusnivellering konfronteres de igen med, at de ikke lever op til det hegemoniske maskulinitetsbillede, ifølge hvilket en mand har succes og høj status, hvorfor den mandlige sygeplejerske burde være læge og ikke sygeplejerske.

Med til ambivalensen hører også, at de mandlige sygeplejersker - selvom de nok bydes velkommen i sygeplejen og nyder stor faglig respekt - alligevel i arbejdet føler sig underlagt det andet køns præmisser; når alt kommer til alt, anser alle parter kvinden for at være den ideelle omsorgsgiver, og derfor er det forventet, at mændene i sygeplejen udøver omsorg efter en kvindelig skabelon. Selvom det er på en anden måde end de kvindelige betjente, konfronteres altså også mændene i sygeplejen med en professionskulturer, der kun tvungent og med stor inerti lader sig omforme (jf. også Baagøe Nielsen 1997).

Den største årsag til ambivalens hos de interviewede mænd er imidlertid jf. Williams begrundet i, at mændene dagligt konfronteres med, at de afviger fra det hegemoniske maskulinitetsbillede:

\footnotetext{
"Mine kammerater har haft utrolig meget sjov med, at jeg skulle tørre røv og sådan noget. Det er lige som om, at alle har en eller anden form for negativ holdning til, at "dét kan du da ikke stå og lave, du kan da ikke lave sådan noget; det må der da være andre (un-
}

derforstået kvinder?) til!?" Det har der været utrolig meget af: "En mand kan da ikke være sygeplejerske!!” (Vilhelm, sygeplejerske).

Den mest udbredte fordom er dog, at de mandlige sygeplejersker, siden de frivilligt påtager sig feminint arbejde, må være feminine og derfor også homoseksuelle. Og fordi mændene oplever, at der stilles spørgsmålstegn ved deres maskulinitet, 'vrider' de sig og søger på alle tænkelige måder konstant at skille sig ud som mænd, at dyrke mandigheden excessivt, at ritualisere og konstituere maskuliniteten, ja man kan tilnærmelsesvis tale om, at de overspiller deres køn og udviser en form for hypermaskulinitet.

De kvindelige betjente møder ligesom de mandlige sygeplejersker en vis grad af vantro og undren over deres beskæftigelse, men denne er ikke forbundet med samme nedvurdering; tværtimod opfattes kvinderne af omgivelserne ofte som 'seje', siden de formår at påtage sig mandearbejde. I forhold til de kvindelige betjente ser vi, at også de oplever ambivalens i forhold til kønsidentiteten. Kvinderne i politiet råder imidlertid ikke bod på deres ambivalens ved at signalere hyperfeminitet; tværtimod nedtoner de deres feminitet for nemmere at kunne begå sig i rollen som politibetjent. Kønsneutralitet $\mathrm{i}$ arbejdslivet synes således at være idealet for mange af de kvindelige betjente, og derfor fremstår kvinderne (jf. også Højgaard 1990) som mere eller mindre utilpassede inden for faget. De kvindelige betjentes utilpassethed kommer bl.a. til udtryk ved, at vi ser en klar tendens til, at kvinderne i første omgang enten undlader at problematisere kønsforskelle eller endog helt benægter disse. I forsøget på at blive en del af helheden og at blive betragtet som en 'normal'/ligeværdig arbejdskraft påtager flere af de interviewede kvinder sig nemlig ansvaret for at råde bod på, at deres nærvær i politistyrken udgør et forstyrrende element; flere af kvinderne udviser således stor tolerance og vælger eksempelvis at fri- 
tage deres mandlige kollegaer og/eller overordnede fra rollen som potentiel undertrykker for derved at afbøde eventuelle spændingsfelter og samtidig selv blive frigjort fra rollen som offer.

At vi på den ene side kan konkludere, at de mandlige sygeplejersker er ambivalente, og på den anden side at de kvindelige betjente er utilpassede er særligt interessant i lyset af, at både ambivalensen og utilpassetheden paradoksalt nok kan siges at udspringe af det samme: Nemlig at de kulturelle forestillinger marginaliserer det kvindelige og ser det som noget negativt - som en substandard - sammenlignet med det mandlige. Man kan således tale om, at de mandlige sygeplejersker tendentielt lider som følge af, at det i samfundet er forbundet med devaluering at udføre kvindearbejde, og derved bliver dilemmaet for mændene i sygeplejen, at de med deres valg af beskæftigelse utilsigtet bryder med det hegemoniske maskulinitetsbillede - mændenes selvforståelse er udpræget maskulin, men de oplever blandt omgivelserne at fremstå som feminine mænd, dvs. umandige. For de kvindelige betjente gælder det, at de i tråd med deres feminine identifikation gerne vil betragtes som feminine, samtidig med at de er bevidste om, at hovedparten af deres overordnede og kollegaer ikke anser det feminine som værende værdifuldt; dilemmaet for kvinderne i politiet bliver altså, at de vil accepteres som kvinder i et fag defineret af og forbundet med maskulinitet og hvor alt det, der associeres med femininitet, betragtes som mindre værd (Bloksgaard \& Faber 2004).

\section{KONKLUSIONER OG PERSPEKTIVER}

Selvom det er muligt at identificere en række ligheder i de mandlige sygeplejersker og de kvindelige betjentes arbejdsliv, er der på en række andre områder så stor forskel på de to køns beretninger, at undersøgelsen med al tydelighed viser, at det i forhold til forskningen om mænd i kvindefag og kvin- der i mandefag ikke er muligt at lade én fælles teori dække begge køn. Der er ikke nogen tvivl om, at Kanter med sin vægtning af det numeriske har fat i noget helt centralt - uligevægt i antalsforhold genererer ganske rigtigt en række ensartede tendenser. Samtidig bekræfter undersøgelsen dog også, at der ikke desto mindre - afhængigt af køn - igangsættes en række temmelig uensartede processer omkring dem, som er i mindretal. En essentiel faktor i forklaringen på hvorfor dét at være 'token' ikke opleves ens eller har samme konsekvenser for de interviewede mænd og kvinder, er, som Williams også hævder, den tætte sammenhæng, der er mellem køn og status/magt. Mænd og mandlighed tæller tilsyneladende mere end kvinder og kvindelighed, og derfor har mænd i mandefag (jf. også Kold 1997) tendentielt mere at miste ved et større antal kvinders indtrængen end kvinder $\mathrm{i}$ de mindre prestigefyldte kvindefag, som opnår øget status ved et større antal mænds indtrængen.

Det, at den samfundsmæssige diskurs om køn hierarkiserer det mandlige over det kvindelige, får, ganske som Williams hævder det, betydning for den organisatoriske adfærd. Vores undersøgelse bekræfter således, at de i samfundet kulturelt funderede forestillinger om og forventninger til køn er væsentlige at have in mente, hvis man skal søge at forstå arbejdsmarkedets kønsopdeling: Bl.a. ses, at mændene i sygeplejen og kvinderne i politiet tilskrives egenskaber og kvalifikationer alene på baggrund af kulturelle og samfundsmæssige opfattelser af henholdsvis maskulinitet og feminitet, at de konstrueres som mand/kvinde og på arbejdspladsen forbindes med symboler/forventninger knyttet til disse to konstruktioner, samt at de på baggrund af ovenstående $\mathrm{i}$ vid udstrækning placeres $\mathrm{i}$ henholdsvis over-/underordnede positioner. Unders $\varnothing$ gelsen bekræfter derfor, at samfundets kønshierarki afspejles og konstitueres i det daglige arbejde på arbejdspladserne dvs. at kønshierarkiet - selv på arbejdspladser, hvor 
mænd og kvinder er ansat på samme niveau og til at udføre det samme arbejde - skabes og genskabes gennem en arbejdsdeling baseret på forestillinger om/uskrevne regler for passende adfærd for de to køn, jf. også Acker.

De barrierer, som de kvindelige politibetjente $i$ interviewundersøgelsen beretter om, er af den slags, som først falder en ind, når man tænker på det kønsopdelte arbejdsmarked: Problemer med at få respekt og autoritet, opnå videreuddannelse og forfremmelse, etc. Disse forhindringer kommer med jobbet enten fra organisationsstrukturerne eller fra de folk, som befolker organisationen. De barrierer, som de mandlige sygeplejersker derimod beretter om, genereres i langt højere grad i mødet med omverdenen, hvor mændene stort set ikke møder andet end stigmatisering og negative stereotyper. Williams kritiserer Kanter for at overse, at mænd tager deres køns privilegier med sig ind i kvindefagene og derfor drager fordel af deres køns universelt anerkendte forrang. Alligevel ender også Williams med at være temmelig statisk i sine konklusioner; bl.a. synes der at være tale om, at hun undervejs overser, at der er grænser for, i hvor høj grad det ene køn tillades at påtage sig det andet køns attributter, og at det derfor heller ikke for mænd universelt anerkendt forrang eller ej - er uproblematisk at trænge ind i et kvindefag.

Ifølge Kanter er numerisk balancering af kvinder og mænd i organisationer en nøglekomponent i forhold til at opnå ligestilling. Undersøgelsen blandt de mandlige sygeplejersker og kvindelige betjente tydeliggør imidlertid, at forskellen på mænds og kvinders muligheder i organisationer i lige så stor grad er begrundet i de forskellige stereotyper knyttet til de to køn, og at en ændring $\mathrm{i}$ forholdene derfor nærmere hænger sammen med en ændring i de hegemoniske kønsbilleder. Eller sagt på en anden måde: Skal kønsarbejdsdelingen på arbejdsmarkedet brydes, handler det om at flytte grænserne for, hvad personer af henholdsvis det ene og det andet køn bør/kan/må, da det kun er herigennem, at dominansforholdet kan opløses. En sådan ændring er imidlertid langt mere træg end en ændring $i$ antal.

\section{LITTERATUR}

- Acker, Joan (1991): "Hierarchies, Jobs, Bodies: A theory of gendered organizations", in Lorber, Judith \& Susan Farell (1991): The Social Construction of Gender. SAGE Publications, London.

- Baagøe Nielsen, Steen (1997): Jagten på den mandlige omsorgskompetence : arbejdspapirer vedr. et indgangsforlob til social- og sundhedsassistentuddannelsen - for mand. Erhvervs- og voksenuddannelsesgruppen, Roskilde Universitetscenter.

- Bloksgaard, Lotte \& Stine Faber (2004): Kon på arbejde - en kvalitativ undersogelse af mandlige sygeplejerskers og kvindelige politibetjentes arbejdsliv. Aalborg Universitetsforlag, Aalborg.

- Dahlerup, Drude (1988): "From a Small to a Large Minority: Women in Scandinavian Politics", in Scandinavian Political Studies (1988).

Vol.11/nr.4.

- Hansen, Lene (1999): Køn på tvors af fag. En analyse af drivkrafter og barrierer for unge, der valger uddannelse utraditionelt for deres køn. CASA (Center for Alternativ Samfundsanalyse), København.

- Holt, Helle (1994): Foreldre på arbejdspladsenen analyse af tilpasningsmulighederne mellem arbejdsliv og familieliv $i$ kvinde- og mandefag. Socialforskningsinstituttet, København.

- Højgaard, Lis (1990): Vil kvinder lede? Et spørgsmål om fornyelse. Ligestillingsrådet, København.

- Kanter, Rosabeth Moss (1977a): Men and Women of the Corporation. BasicBooks, New York. - Kanter, Rosabeth Moss (1977b): "Some effects of Proportions on Group Life: Skewed sex ratios and Responses to token women", in American Journal of Sociology. Vol. 82, Issue 5, 965-990.

- Kold, Vibeke (1997): "Det kønne arbejde - faktorer, processer og aktører på det kønsopdelte arbejdsmarked", in Emerek, Ruth et al.: Brydninger - Perspektiver på det konsopdelte arbejdsmarked. Arbejdsmarkedsstyrelsen, København.

- Kvande, Elin \& Bente Rasmussen (1990): Nye kvinneliv. Kvinner $i$ menns organisasjoner. Ad Notam Forlag A/S, Oslo.

- Lindgren, Gerd (1985): Kamrater, kollegor och kvinnor - en studie av könssegregerings-processen $i$ två mansdominerade organisationer. Umeå Universitet, Umeå. 
- Martin, Susan Erlich (1980): Breaking and Entering. Policewomen on Patrol. University of California Press, Berkeley.

• Nexø Jensen, Hanne (1990): "En kønnere organisationsteori”, in Peter Bogason (red.) (1990): Nyere tendenser $i$ politologien. Stat og forvaltning. Forlaget politiske studier, København.

- Williams, Christine L. (1995): Still a man's world - men who do women's work. University of California Press, Ltd, London.

\section{SUMMARY}

Women's movement into male-dominated occupations has been well researched over the past decades. This series of research can be traced back to Rosabeth Moss Kanter's seminal theory of tokenism (Kanter 1977a), a demographic composition theory, which states that individuals become "tokens" when they are such a small minority that they are seen as symbols of their particular category rather than as individuals. Although research on underrepresentation has often been done on women, men in the minority more recently have become a subject of interest as the number of men entering and succeeding in female-dominated occupations has risen (e.g. Williams 1995). In pursuing this newer line of research, this essay refers to a recent Danish study of male nurses and female police officers in order to explain how the experiences of a minority of men working with a female majority compares to those of a minority group of women working with a male majority.

Stine Thidemann Faber cand.scient.soc, ph.d.-stipendiat Aalborg Universitet 